\title{
Abundance of Soil Insect Pests in Florida Sugarcane ${ }^{1}$
}

\author{
Ron Cherry, Mabry McCray, Hardev Sandhu, and Michael Karounos ${ }^{2}$
}

Soil insects are economically important pests for Florida sugarcane growers in the Everglades Agricultural Area (EAA). This publication presents surveys of these pests from 2015 and 2016, compares them to several historical surveys, and examines the association of soil parameters (its acidity, calcium, magnesium, and silicon content, and depth) with the abundance of the pests. The intent of this document is to inform sugarcane growers, scouts, pesticide applicators, and researchers on fluctuations of economically important pests with implications on their management.

\section{Wireworms}

Historically, wireworms (Coleoptera: Elateridae) were the first soil insects surveyed causing significant damage in Florida sugarcane (Bregger et al. 1959). Hall (1988) reported twelve species of wireworms in the crop. Past surveys have shown that the corn wireworm, Melanotus communis (Gyllenhal) is the species causing the most economic damage (Figures 1 and 2).

Abundance of soil insect pests from 20 commercial sugarcane fields (sampled 2015 and 2016) is shown in Table 1. Insects were collected from intact sugarcane stools by hand. Sampling was done post-harvest for easier access to fields. For more detailed methods on survey sampling, see Changes in the Relative Abundance of Soil-Dwelling Insect Pests in Sugarcane Grown in Florida, on which this publication was based: Cherry et al. (2017), https:// doi.org/10.18474/JES16-33.1.

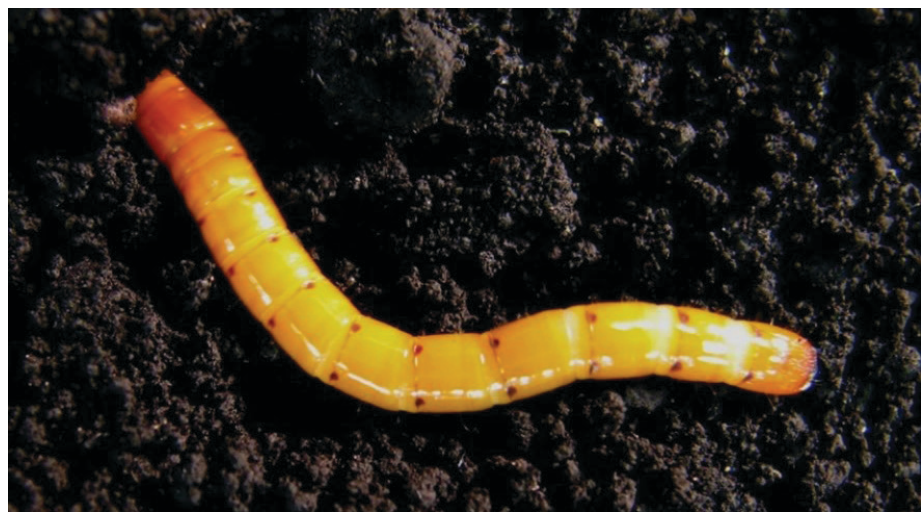

Figure 1. Melanotus communis wireworm (Coleoptera: Elateridae). Credits: Mike Karounos

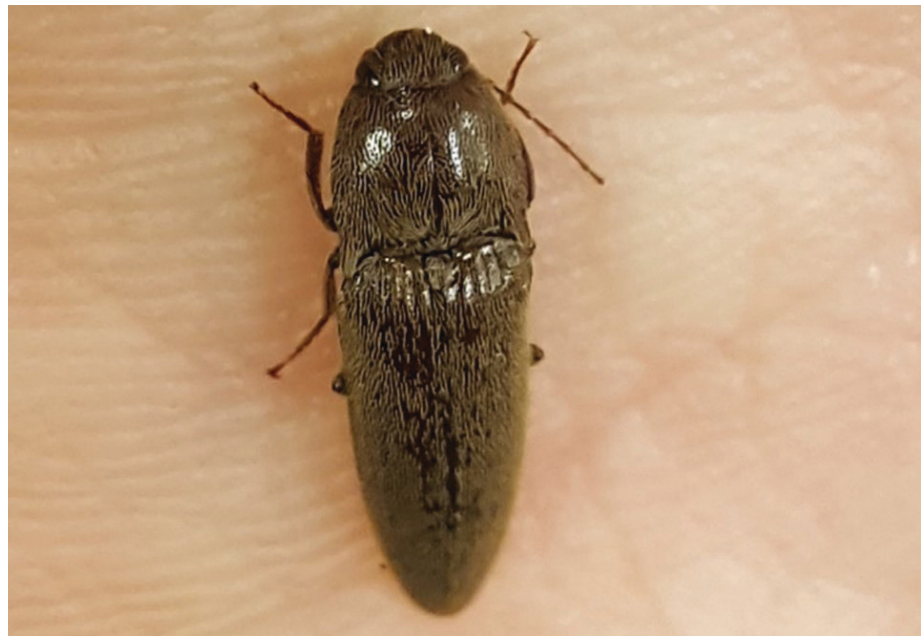

Figure 2. Melanotus communis adult click beetle (Coleoptera: Elateridae).

Credits: Mike Karounos

1. This document is ENY-2058, one of a series of the Entomology and Nematology Department, UF/IFAS Extension. Original publication date February 2021. Visit the EDIS website at https://edis.ifas.ufl.edu for the currently supported version of this publication.

2. R. H. Cherry, professor, Entomology and Nematology Department; M. McCray, scientist, Agronomy Department; H. Sandhu, assistant professor, Agronomy Department; and M. Karounos, biological scientist, Entomology and Nematology Department; UF/IFAS Everglades Research and Education Center, Belle Glade, FL 33430.

The Institute of Food and Agricultural Sciences (IFAS) is an Equal Opportunity Institution authorized to provide research, educational information and other services

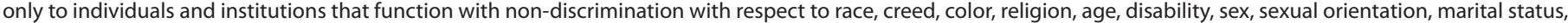

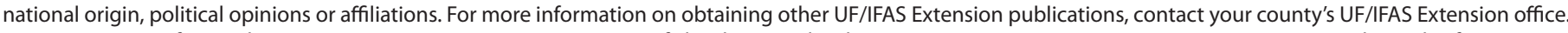
U.S. Department of Agriculture, UF/IFAS Extension Service, University of Florida, IFAS, Florida A \& M University Cooperative Extension Program, and Boards of County Commissioners Cooperating. Nick T. Place, dean for UF/IFAS Extension. 
In our survey, the corn wireworm, $M$. communis, was clearly the dominant wireworm species (88\%). This has been the most important wireworm species in Florida sugarcane for a long time (Hall 1988). The species was added to the EPPO A1 action list of quarantine pests in 2002 (OEPP/EPPO 2005).

\section{White Grubs}

The second group of soil insect pests reported causing significant damage in Florida sugarcane historically were white grubs (Coleoptera: Scarabaeidae) (Figure 3).

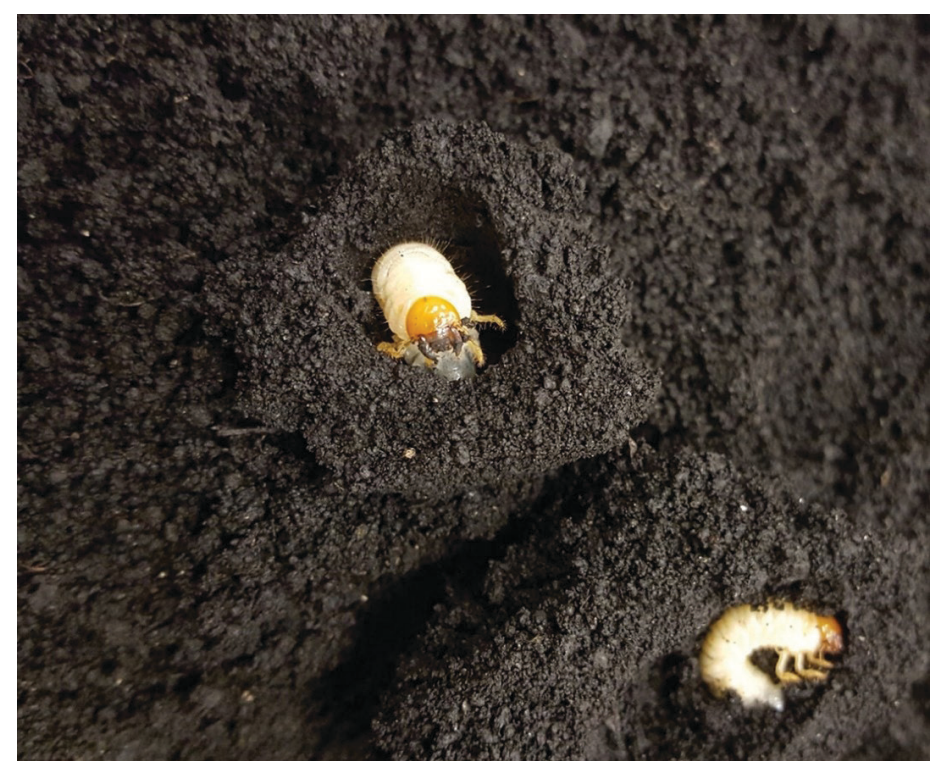

Figure 3. White grubs (Coleoptera: Scarabaeidae).

Credits: Mike Karounos

Gordon and Anderson (1981) reported on significant grub damage first observed in 1971. Six species were associated with the crop, with Tomarus subtropicus (Blatchley) causing the most economic damage. In 1988, Cherry found that T. subtropicus was the largest and most abundant grub. In 1994, Stansly et al. determined T. subtropicus was $23 \%$ of all grubs found in muck soils.

In recent years, however, $\mathrm{R}$. $\mathrm{H}$. Cherry has observed what appears to be a major change in the relative abundance of soil insect pests, especially scarabs, in Florida sugarcane (noted in the insect management chapter of the UF/IFAS Sugarcane Handbook).

In our 2015 and 2016 surveys, we observed four of the six scarab grub species ranging from $20 \%$ to $30 \%$ in relative abundance. Cyclocephala parallela Casey and Phyllophaga latifrons (LeConte) are occasional pests of Florida sugarcane; Anomala marginata (F.) and Dycinetus morator (F.) are not. Gordon and Anderson (1981) reported Euphoria sepuchralis (F.) to be associated with Florida sugarcane although not causing damage. We did not find this latter species in any of our samples. Of special interest are our findings with T. subtropicus (Figures 4 and 5).

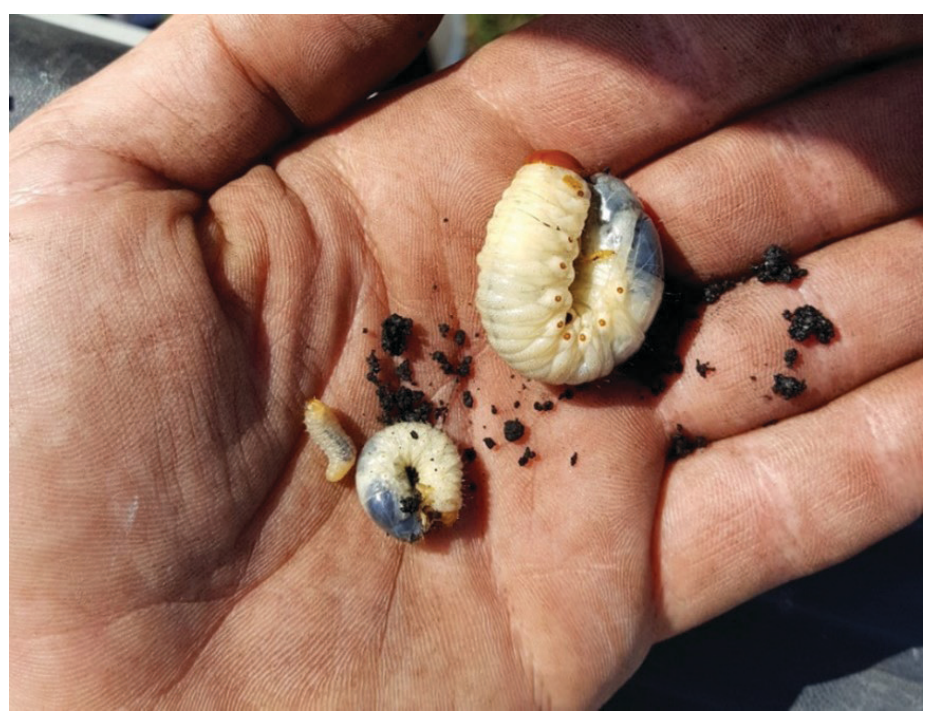

Figure 4. Diaprepes grub (left), a typical scarab grub (middle), and a Tomarus subtropicus grub (right). Typical size differences. Credits: Mike Karounos

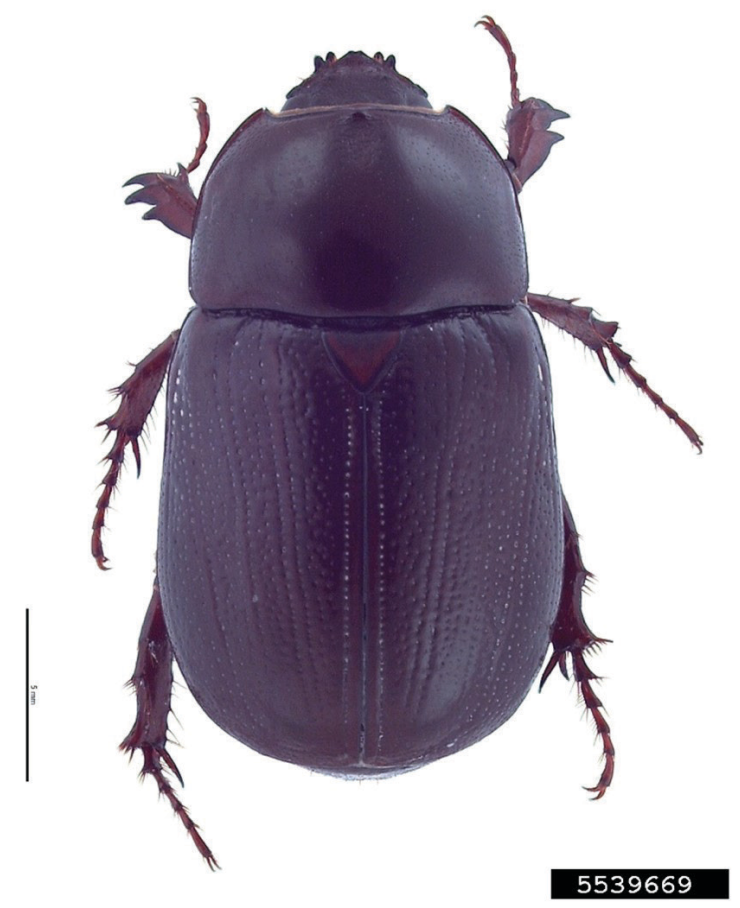

Figure 5. Tomarus subtropicus adult female (Coleoptera: Scarabaeidae). Credits: Emmy Engasser, Hawaiian Scarab ID, USDA APHIS PPQ, Bugwood.org

Our study was conducted using methods very similar to the historical surveys. However, despite sampling more fields, we found no T. subtropicus in our 2015 and 2016 surveys. This is consistent with R. H. Cherry's observation that no incidences of grub damage in Florida sugarcane have been reported during the last ca. 20 years while working in the heart of Florida sugarcane. Hence, what was once the 
most important soil insect pest of Florida sugarcane has essentially disappeared in sugarcane fields, ceasing to be a problem. What exactly caused this major shift is unknown.

\section{Root Weevil}

Diaprepes root weevil (Curculionidae), Diaprepes abbreviatus (L.), is an important pest of sugarcane and citrus in various islands of the Caribbean. It has long been a pest in Florida citrus. In 2010, infestations of the weevil were observed causing damage to Florida sugarcane for the first time (Cherry et al. 2011) (Figure 6).

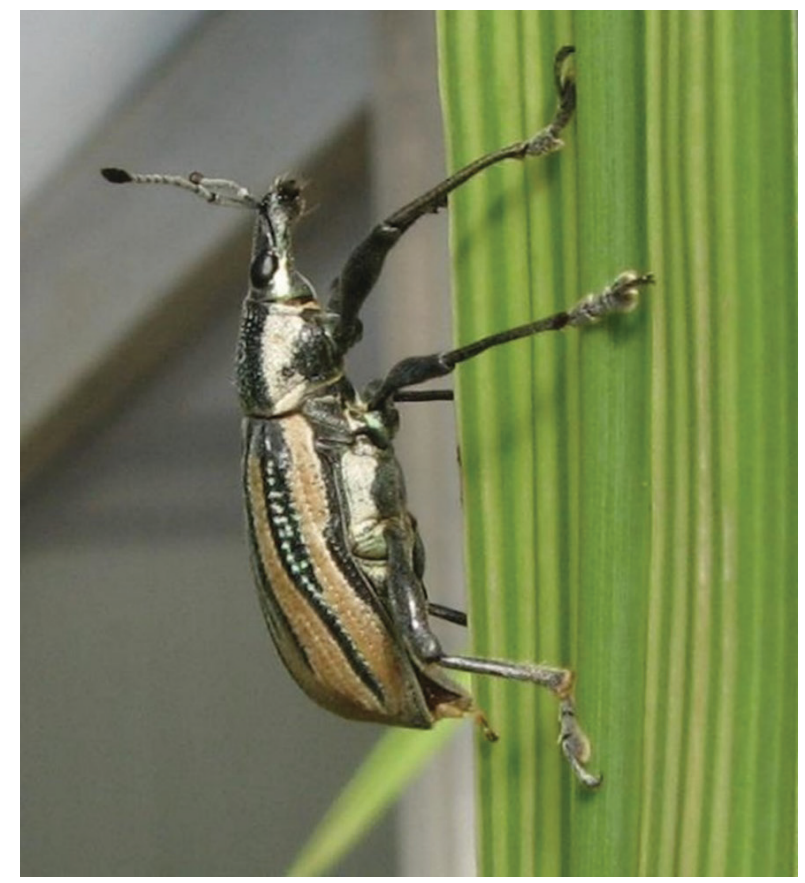

Figure 6. Diaprepes abbreviatus sugarcane root weevil adult on sugarcane.

Credits: Ron Cherry

The only weevil (Coleoptera: Curculionidae) species found in the 2015 and 2016 surveys was D. abbreviatus. However, only 13 larvae were found in all samples from 20 fields. This would indicate the insect has not become a serious pest in Florida sugarcane.

\section{Survey Summary}

No new unknown soil insect pests were found in the 2015 and 2016 surveys. Very few sugarcane root weevils were found. This shows that in Florida sugarcane, this pest is still uncommon. The once important grub pest, T. subtropicus was not even detected in fields. Finally, wireworms and especially grubs found in fields were positively correlated with muck soil depth (Figure 7 and Table 2).

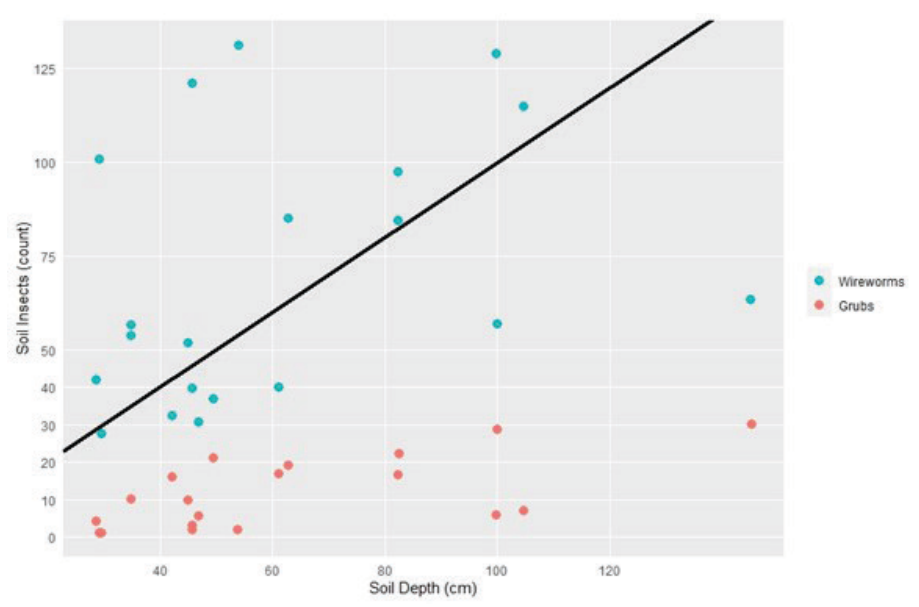

Figure 7. Linear regression of grubs/field in 20 sugarcane fields with soil depth of fields.

Two factors have increased flooding, which is effective in reducing soil insect populations, in the Everglades Agricultural Area (EAA). (See "Management by Flooding", below.) Best management practices (BMP) including water held during the rainy season by growers reducing phosphorous discharge is the first factor. Second is organic matter oxidation due to the drainage of organic (muck) soils. This has led to the prevalence of shallow soils in the EAA, and these shallow soils are frequently flooded (Jennewein et al. 2016). This phenomenon of soil subsidence has been documented and researched by soil and water scientists at the Everglades Research and Education Center for decades (Figure 8).

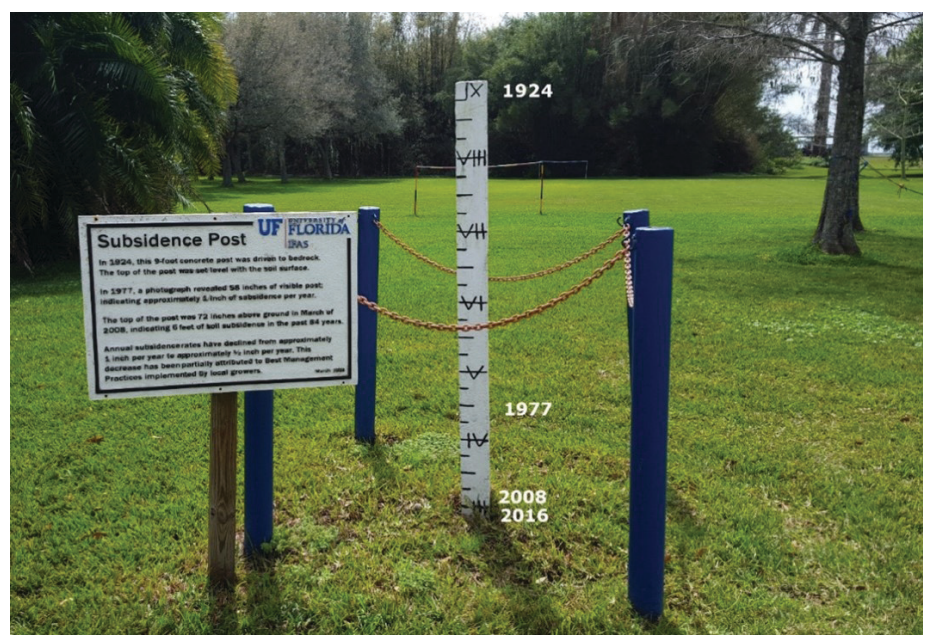

Figure 8. Subsidence post at the UF/IFAS EREC in Belle Glade, FL. Note: Post marks show soil depth in previous years. This may not be typical of other areas, because it has no crops and is drained most of the year. Credits: Mike Karounos

\section{Management by Flooding}

There are more publications on flooding for soil insect control for southern Florida than for anywhere else in the world. Flooding either fallow fields or by rotation with rice cultivation is a part of best management practices in the EAA and is recommended in many other UF/IFAS 
publications for sugarcane soil insect IPM. Flooding can kill soil insects directly by drowning them, or it can kill them indirectly by exposing them to predation, often by diverse and abundant birds (Figure 9).

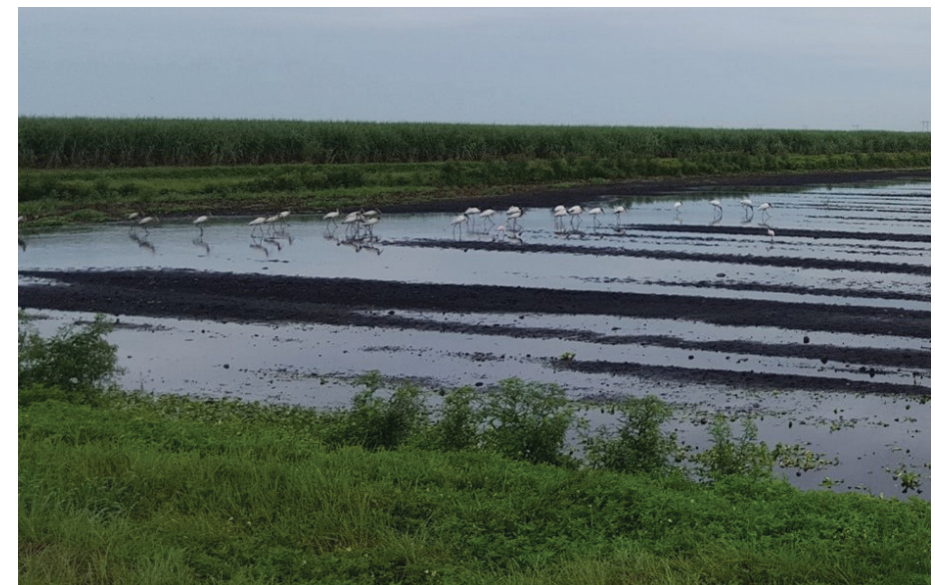

Figure 9. Wood storks foraging in a naturally flooded sugarcane field. Credits: Mike Karounos

Wireworms in Florida sugarcane are more flood tolerant than grubs (Hall and Cherry 1993). Among grubs tested in the EAA, T. subtropicus is the least flood tolerant, which may partially explain its disappearance (Cherry et al. 1990).

For wireworms, flooding during late spring and summer will kill the wireworms and prevent egg-laying by the adult click beetles. Thus, flooding fallow fields or growing flooded rice as a rotation crop reduces wireworm infestations. Flooding can be effective if it is maintained continuously for a minimum of six weeks during the summer. Longer flooding periods are needed during colder months (Cherry 2017).

Short-term flooding for grubs is most efficient in August, when water temperatures are warm, rainfall is abundant, and grubs initiate feeding. Discing infested fields and decreasing the number of ratoon crops also reduce white grub infestations (Beuzelin et al. 2019).

For further information, please see Cherry, McCray, and Sandhu (2017), from which this publication was adapted.

\section{References}

Beuzelin, J. M., R. H. Cherry, G. S. Nuessly, and H. S. Sandhu. 2019. Insect Management in Sugarcane. ENY-406 Gainesville: University of Florida Institute of Food and Agricultural Sciences. https://edis.ifas.ufl.edu/ig065
Bhadha, J. H., A. L. Wright, and G. H. Snyder. 2020. Everglades Agricultural Area Soil Subsidence and Sustainability. SL-311. Gainesville: University of Florida Institute of Food and Agricultural Sciences. https://edis.ifas.ufl.edu/ss523

Bregger, T., P. Dunckelman, F. LeGrand, E. Todd, and D. Questel. 1959. "A Brief Review of Sugarcane Research in Florida, 1939-1959." Annual Proceedings of the Soil and Crop Science Society of Florida 19:287-294.

Buss, E. A. 2018. Sugarcane Grub, Tomarus subtropicus Blatchley (Insecta: Coleoptera: Scarabaeidae). EENY318. Gainesville: University of Florida Institute of Food and Agricultural Sciences. https://edis.ifas.ufl.edu/in593

Cherry, R. 1988. "Correlation of Crop Age with Populations of Soil Insect Pests in Florida sugarcane." Journal of Agricultural Entomology 4:241-245.

Cherry, R. 2017. Wireworms in Florida Sugarcane. ENY665. Gainesville: University of Florida Institute of Food and Agricultural Sciences. https://edis.ifas.ufl.edu/sc013

Cherry, R., F. Coale, and P. Porter. 1990. "Oviposition and Survivorship of Sugarcane Grub (Coleoptera: Scarabaeidae) at Different Soil Moistures." Journal of Economic Entomology 83:1355-1359.

Cherry, R., D. Hall, A. Wilson, and L. Baucum. 2011. "First Report of Damage by the Sugarcane Root Weevil Diaprepes abbreviatus (Coleoptera: Curculionidae) to Florida Sugarcane." Florida Entomologist 94:1063-1065.

Cherry, R., M. McCray, and H. Sandhu. 2017. "Changes in the Relative Abundance of Soil-Dwelling Insect Pests in Sugarcane Grown in Florida." Journal of Entomological Sciences 52 (2): 169-176. https://doi.org/10.18474/JES16-33.1

Cherry, R. and P. Stansly. 2008. "Abundance and Spatial Distribution of Wireworms (Coleoptera: Elateridae) in Florida Sugarcane Fields on Muck versus Sandy Soils." Florida Entomologist 91:383-387.

Daroub, S. H., T. A. Lang, O. A. Diaz, and M. Chen. 2018. Best Management Practices in the Everglades Agricultural Area: Controlling Particulate Phosphorus and Canal Sediments. SL228. Gainesville: University of Florida Institute of Food and Agricultural Sciences. https://edis.ifas.ufl.edu/ ss 448 
Gill, H. K., G. Chahil, G. Goyal, J. L. Gillett-Kaufman, and R. Cherry. 2017. "Corn wireworm Melanotus communis Gyllenhal (Insecta: Coleoptera: Elateridae).” EENY584. Gainesville: University of Florida Institute of Food and Agricultural Sciences. https://edis.ifas.ufl.edu/in1025

Gordon, R., and D. Anderson. 1981. "The Species of Scarabaeidae (Coleoptera) Associated with Sugarcane in South Florida." Florida Entomologist 64:119-138.

Hall, D. 1988. "Insects and Mites Associated with Sugarcane in Florida." Florida Entomologist 71:138-150.

Hall, D., and R. Cherry. 1993. "Effect of Temperature on Flooding to Control the Wireworm Melanotus communis (Coleoptera: Elateridae)." Florida Entomologist 76:155-160.

Jennewein, S., S. Daroub, J. Bhadha, T. Lang, M. Singh, and M. McCray. 2016. "Managing Shallow Organic Soils to Maximize Sugarcane Yield in the Everglades Agricultural Area." Sugar Journal 79:22.

McCray, J. M., H. S. Sandhu, R. W. Rice, and D. C. Odero. 2019. Nutrient Requirements for Sugarcane Production on Florida Muck Soils. SS-AGR-226. Gainesville: University of Florida Institute of Food and Agricultural Sciences. https:// edis.ifas.ufl.edu/sc026

OEPP/EPPO. Melanotus communis. 2005. Data sheets on quarantine pests. Bull. 35:380-382.

Stansly, P., R. Cherry and O. Sosa Jr. 1994. "Relative Abundance of White Grubs (Coleoptera: Scarabaeidae) in Florida Sugarcane on Sand and Muck Soils". Journal of the American Society of Sugar Cane Technologists 14:19-24.

Weissling, T. J., J. E. Peña, R. M. Giblin-Davis, and J. L. Knapp, Jr. 2019. Diaprepes Root Weevil, Diaprepes abbreviatus (Linnaeus) (Insecta: Coleoptera: Curculionidae). EENY024. Gainesville: University of Florida Institute of Food and Agricultural Sciences. https://edis.ifas.ufl.edu/in151 
Table 1. Abundance of soil insect pests in Florida sugarcane fields.

\begin{tabular}{|c|c|c|c|}
\hline \multirow[b]{2}{*}{ Family } & \multirow[b]{2}{*}{$\%$ fields } & \multicolumn{2}{|c|}{ Abundance } \\
\hline & & Total & Relative $^{1}$ \\
\hline \multicolumn{4}{|l|}{ Curculionidae } \\
\hline Diaprepes abbreviatus (L.) & 20 & 13 & 100 \\
\hline \multicolumn{4}{|l|}{ Elateridae } \\
\hline Conoderus spp. & 80 & 51 & 4 \\
\hline Glyphonyx bimarginatus Schaeffer & 75 & 84 & 6 \\
\hline Ischiodontus spp. & 10 & 21 & 2 \\
\hline Melanotus communis (Gyllenhal) & 100 & 1232 & 88 \\
\hline \multicolumn{4}{|l|}{$\underline{\text { Scarabaeidae }}$} \\
\hline Anomala marginata (Fab.) & 45 & 47 & 20 \\
\hline Cyclocephala parallela Casey & 70 & 68 & 29 \\
\hline Dyscinetus morator (Fab.) & 15 & 47 & 20 \\
\hline Euphoria sepulchralis (Fab.) & 0 & 0 & 0 \\
\hline Phyllophaga latiforons (LeConte) & 75 & 69 & 30 \\
\hline Tomarus subtropicus (Blatchley) & 0 & 0 & 0 \\
\hline
\end{tabular}

Table 2. Linear correlations ${ }^{1}$ of soil insects with different soil parameters.

\begin{tabular}{|l|c|c|c|c|c|}
\hline \multicolumn{1}{|c|}{ Family } & $\mathbf{p H}$ & $\mathbf{C a}\left(\mathbf{g} / \mathbf{m}^{3}\right)$ & $\mathbf{M g}\left(\mathbf{g} / \mathbf{m}^{3}\right)$ & Si $\left(\mathbf{g} / \mathbf{m}^{3}\right)$ & $\mathbf{D e p t h}(\mathbf{c m})$ \\
\hline Elateridae & 0.390 & -0.125 & 0.051 & 0.203 & 0.346 \\
\hline Scarabaeidae & -0.064 & -0.195 & -0.203 & 0.270 \\
\hline Total & 0.379 & -0.179 & -0.002 & 0.278 \\
\hline
\end{tabular}

${ }^{1}$ Linear correlation of total insects in taxon in a field with soil parameters of the field $(\mathrm{N}=20$ fields). Correlations greater than $\mathrm{r}= \pm 0.44$ are significant at $a=0.05$ 